\title{
Consumer Preference on Instant Noodles in Kathmandu City
}

\begin{abstract}
Kailash Patendra Amatya*
\section{Abstract}

This paper attempts to measure customer preference on instant noodles in Kathmandu City. Descriptive and causal research design was used. 100 samples were taken through structured questionnaires. Convenient sampling was used. Descriptive and correlation analysis was done to analyse the data and to test the hypothesis. This study confirmed that brand, price, quality, taste, easy and fast and availability is factors for purchasing noodles in Kathmandu City.
\end{abstract}

Keywords: customer preference, noodles, Kathmandu City.

\section{Introduction}

Customer preference means choosing one product than another. Consumer purchases those products giving more value to him/her (Auty, 1999). Customer preference is affected by various factors like brand, price, quality of the product, taste, comfortable and availability of it (Golub \& Biknley, 2005; Thiyagaraj, 2015; Sowunmi, Omigie \& Daniel, 2014). Customer preference motivates psychologically a person towards making decision of purchase (Lichtenstein \& Slovic, 2006).

Instant noodles are a type of noodles which can be made easily and quickly, usually by adding hot water (Oxford advance learner's dictionary, 2005). Instant noodles are dried or precooked noodles and often sold with packets of flavoring including seasoning oil. Precooked noodles can be reheated or eaten straight from packet. Instant noodles are often criticized as unhealthy or junk food. A single serving of instant noodles is high in carbohydrates and fat, but low in fiber, vitamins and minerals. The addition of fresh chopped vegetables and/or healthy lean meat or fish to the finished noodle soup can add some nutritional value. Instant noodles were invented by Momofuku Ando of Nissin Foods, Japan (BBC News, 2007 cited in Instant Noodles, n.d). According to a Japanese poll in the year 2000, "the Japanese believe that their best invention of the twentieth century was instant noodles." As of 2010, approximately 95 billion servings of instant noodles are eaten worldwide every year (BBC News, 2007 cited in Instant Noodles, n.d).

\footnotetext{
* Dr. Amatya is Associate Professor, Tribhuvan University, Faculty of Management, Shanker Dev Campus Email: amatyakailash@hotmail.com
} 
Noodles are one of the most popular varieties of food, which the people have been using since its production started. The consumption practice in Nepal is not very old. Before 2017 B.S. only those people who have gone out of the country knew about noodles on business basis. Noodles were first produced in the Nepalese market after 2017 B.S. and it started supplying in market in full commercially in the market since 2032 B.S. Instant noodles are very famous in Nepal. In the early 1980s Gandaki oodles (P) Ltd of Pokhara City introduced Rara, a white instant noodles. Then in around 1985, Chaudhary Group (CG) entered the market with WaiWai. Wai-Wai noodles, a brown, spicy and precooked noodle became a big hit among the people. In 2032 B.S., the national trading limited imported the equipment and machines required to produce noodles in Nepal and the production of plain noodles was started from that year after the establishment of Gandaki noodles. After then gradually people started knowing about the commercial importance and the popularity of different taste of instant noodles thus gradually other manufacturers started rising. Presently various brand of instant noodles are manufactured by different factory with different taste. Instant noodles are very ready made food. It can also prepare in few minutes. So it is named as instant noodles. More than two dozen on instant noodles are presently in Nepalese market.

\section{Statement of the Problem}

Noodles are popular in Nepalese consumers. Nowadays, the working pressure of many people has been increased sharply in modern times. In order to save time, it has been a common habit to eat instant noodles in our daily life. Therefore, instant noodles are a kind of essential food. The issue of the study is related to consumer's preference on instant noodles in Kathmandu. The absence of satisfaction among its customer may lead to the disaster like decrease in sales of its product and also in its profit, as it is running successfully though winning the heart of the million Nepalese people by providing the quality product and services. Therefore the report aims at finding out the current situation of marketing condition and the sales analysis of instant noodles.

\section{Research Questions}

This study makes an attempt to address the following questions:

What features attract more consumers to the instant noodles?

Which instant noodle is most preferable among the instant noodles categories?

Which of these variables (i.e. price, quality, quantity and taste) have adverse effect on consumer's preference on instant noodles in Nepal?

\section{Objectives of study}

Following are the objectives of the study:

To find out the level of awareness among the people towards the product such as price, quantity, quality and taste.

To find out most preferable noodles in Nepal. 


\section{Development of Hypothesis}

H1: Brand is related to customer preference in purchasing noodles.

$\mathrm{H} 2$ : Price is related to customer preference in purchasing noodles.

H3: Quality is related to customer preference in purchasing noodles.

H4: Taste is related to customer preference in purchasing noodles.

H5: Easy and fast is related to customer preference in purchasing noodles.

H6: Availability is related to customer preference in purchasing noodles.

Research framework is shown in Figure 1.

Figure 1: Research Framework

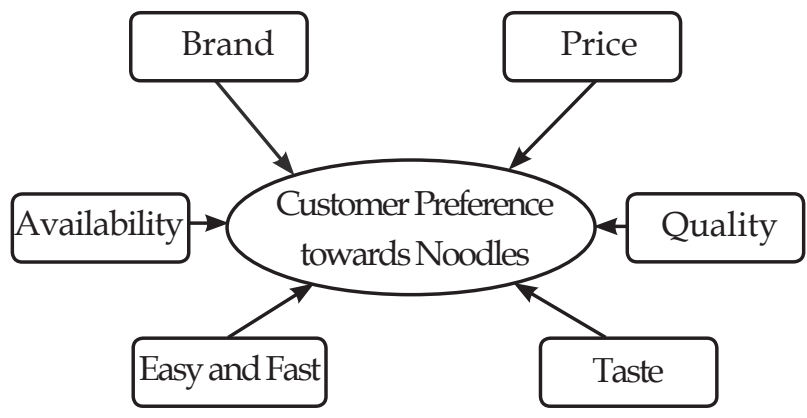

\section{Research Methodology}

Research methodology is a systematic way of recording of controlled observations that may lead to the development of generalization principles of theories, resulting in prediction and possibility ultimate control of events. It deals with the data collection activities. A research design encompasses the methodology and procedures employed to a conduct scientific research. Generally it describes the general plan for collecting, analyzing and evaluating data after identifying. The design of this study is descriptive as well as analytical in nature. Descriptive and Causal research design was used in this research.

Data were collected through primary source. Direct responses of the respondents were taken through self-administered questionnaire. Data were generated in five point Likert scale is anchored by "strongly disagree'" = ' 1 ' to "strongly agree" $=$ ' 5 '.

All the consumers of instant noodles in Kathmandu valley are considered as the population for this study. So, a simple convenient random sampling is used to obtain the samples from the population. 100 questionnaire were distributed to the respondent in different location of Kathmandu valley and responses have been successfully obtained.

Out of 100 respondents, 74 of the respondents fall between the age category of $18-25$ with the percent of 74, 16 of the respondents fall under the category 25-35 with the percent of 16 , and the rest fall under the category above 35 . Majority of the respondents are students with the percentage of 74 whereas, least of the respondents are businessmen with the percentage of 2 . 
Most of the respondents are male with the percentage of 66 and the rest of the respondents are female with the percentage of 34 .

Descriptive Statistics is used in this study for analyzing data. One sample t-test is used to test hypothesis. Correlation analysis was done to find out the relationship between dependent and independent variables.

The limitation the studies are as- Data used in the study have been obtained from primary source through structured questionnaire method. The sample size is small; therefore the result cannot accurately be generated to the wider population of interest. Respondents were chosen using convenient sampling method. All the data are collected in Kathmandu valley only.

\section{Results and Discussion}

\section{Popular Brand}

Most preferred instant noodle is Wai-Wai whereas, the least preferred is Ruchee noodles.

\section{Type of Food}

Most of the respondents consume instant noodles as lunch whereas, least of respondents consume instant noodle as morning meal.

\section{Number of Consumption}

Ninety percent of respondents consume the instant noodles one to two times in a week, six percent of respondent consume two to four times in a week and four percent of respondent consume more than four times in a week.

\section{Media}

Consumer gets the information about instant noodles through television, poster and pamphlets, newspaper and F.M.

\section{Descriptive Statistics}

Table 1: Descriptive Statistics of Items

\begin{tabular}{|l|c|c|}
\hline Particular & Mean & Std. Deviation \\
\hline Brand & 4.11 & 0.61 \\
\hline Price & 4.35 & 0.59 \\
\hline Quality & 4.44 & 0.51 \\
\hline Taste & 4.02 & 0.35 \\
\hline Easy and fast & 4.53 & 0.31 \\
\hline Availability & 4.42 & 0.44 \\
\hline Customer Preference & 4.34 & 0.42 \\
\hline Overall Average & $\mathbf{4 . 2 3}$ & $\mathbf{0 . 8 0}$ \\
\hline
\end{tabular}


Table 1 shows the mean of brand, price, quality, taste, easy and fast, availability and customer preference is above the level of 3 and standard deviation below 1 . This shows the data presented in Table 1 follows the normal distribution. Brand, price, quality, taste, easy and fast and availability are the important factors of customer preference.

\section{Correlation Analysis}

Table 2: Correlation Matrix

\begin{tabular}{|c|c|c|}
\hline Customer Preference & Correlation & 1 \\
\hline & Sig. & \\
\hline \multirow[t]{2}{*}{ Brand } & Correlation & .46 \\
\hline & Sig. & 0.00 \\
\hline \multicolumn{3}{|l|}{ Price } \\
\hline & Correlation & 0.37 \\
\hline & Sig. & 0.00 \\
\hline \multicolumn{3}{|l|}{ Quality } \\
\hline & Correlation & 0.47 \\
\hline & Sig. & 0.00 \\
\hline \multicolumn{3}{|l|}{ Taste } \\
\hline & Correlation & 0.47 \\
\hline & Sig. & 0.00 \\
\hline \multirow[t]{2}{*}{ Easy and fast } & Correlation & 0.04 \\
\hline & Sig. & 0.54 \\
\hline \multirow[t]{2}{*}{ Availability } & Correlation & 0.51 \\
\hline & Sig. & 0.00 \\
\hline $\begin{array}{l}{ }^{*} \text { Correlation is significant } \\
{ }^{*} \text { Correlation is significar }\end{array}$ & $\begin{array}{l}\text { el (2-tailed). } \\
\text { el (2-tailed). }\end{array}$ & \\
\hline
\end{tabular}

Table 2 expresses that brand, price, quality, taste, easy and fast and availability is moderately correlated with customer preferences.

\section{Hypothesis Testing}

Hypothesis is tested on correction matrix from Table 2.

\section{H1: Brand is related to customer preference in purchasing noodles.}

$\mathrm{p}$-value of brand and customer preference is 0.00 which is less than 0.05 . So, H1 is accepted. Brand is related to customer preference.

\section{H2: Price is related to customer preference in purchasing noodles.}

p-value of price and customer preference is 0.00 which is less than 0.05 . So, H2 is accepted. Price is related to customer preference. 


\section{H3: Quality is related to customer preference in purchasing noodles.}

p-value of quality and customer preference is 0.00 which is less than 0.05 . So, H3 is accepted. Quality is related to customer preference.

H4: Taste is related to customer preference in purchasing noodles. p-value of taste and customer preference is 0.00 which is less than 0.05 . So, H4 is accepted. Taste is related to customer preference.

H5: Easy and fast is related to customer preference in purchasing noodles. p-value of easy and fast is 0.00 which is less than 0.05 . So, H5 is accepted. Easy and fast is related to customer preference.

\section{H6: Availability is related to customer preference in purchasing noodles. \\ p-value of availability is 0.00 which is less than 0.05 . So, H6 is accepted. Availability is related to customer preference.}

\section{Discussion and Conclusion}

The study was conducted to analyze the consumers' preference on instant noodles in Kathmandu valley. The findings conclude that the most effective media for advertising is Television, newspaper, F.M. etc.

This research provides the instant noodles companies with an insight to understand how to increase the consumer preference level. Wai-Wai is most preferred brand. Ruchee is least preferred brand. Noodles in sought at lunch time. Brand, price, quality, taste, easy and fast and availability are the important factors of customer preference in purchasing noodles.

\section{References}

Auty, S. (1992).Consumer choice and segmentation in the restaurant industry. The Service Industries Journal, 12(3), 324-339.

Chaudhary Group. (n.d.). Retrieved from http://_en.wikipedia.org/wwiki/Chaudry__Group

Golub, A., \& Binkley, J.J. (2005). Consumer choice of breakfast cereals purchase patterns of foods with salient nutrition characteristics. Department of Agricultural Economics, Purdue University.

Instant Noodles. (n.d). Retrieved form http://en.wikipedia.org/wiki/BBC News

Oxford (2005). Oxford Advance Learner's Dictionary. Retrived from http://en.wikipedia. org/wiki/Oxford Advanced Learner's Dictionary

Sowunmi, F.A., Omigie, O.C., \& Daniel, D.T. (2014). Consumers' perception on Ofada rice in Ibadan North Local Government area of Oyo State, Nigeria. Journal of Economics and Sustainable Development, 5(16), 78-86.

Thiyagaraj, V. (2015). A study of consumer preference towards branded tea in Tiruppur City. Retrieved from http://theglobaljournals.com/gra/file.php?val=May_2015_1431349 833_1431349877.pdf 